\title{
Clean Sweeps: Protecting Officer Safety and Preventing the Imminent Destruction of Evidence
}

\author{
Catherine A. Fiske†
}

After lawfully entering a home to arrest a suspect, a police officer hears suspicious noises from a remote corner of the premises. She thinks, "The fourth amendment requires a search warrant, but I haven't got one. What if that sound is someone with a gun? Or someone destroying evidence? What should I do?" Despite her uncertainty, she conducts a quick sweep of the residence and discovers, in the attic, a pound of marijuana and a cat. Because hidden confederates can create dangers, lower courts are upholding protective sweeps ${ }^{1}$ such as this one, a cursory warrantless search of the premises for people, but not for things.

Is this proper? The fourth amendment protects individuals against unreasonable searches and seizures. ${ }^{2}$ In general, before police can engage in a search or seizure, the Constitution requires that an objective magistrate issue a warrant based upon probable cause. In the context of residential searches, this requirement operates as a safeguard against arbitrary police intrusion into the privacy of the home. ${ }^{3}$ Yet there are circumstances, "jealously and carefully drawn," 4 where courts have interpreted the Constitution not to require police officers to obtain warrants.

$\dagger$ B.A. 1983, Brown University; J.D. Candidate 1988, The University of Chicago.

- Courts have used a number of terms to describe the protective sweep, including "safety sweep," "security check," and "cursory sweep." For purposes of this comment, the terms are interchangeable.

${ }^{2}$ The fourth amendment to the U.S. Constitution states:

The right of the people to be secure in their persons, houses, papers, and effects, against unreasonable searches and seizures, shall not be violated, and no Warrants shall issue, but upon probable cause, supported by Oath or affirmation, and particularly describing the place to be searched, and the persons or things to be seized.

${ }^{3}$ A magistrate's review serves two functions. It prevents judgment by hindsight, whereby a search is validated just because it happened to be successful, and it interposes an objective outsider who is detached from the events that led the police officer to her conclusions.

4 Jones v. United States, 357 U.S. 493, 499 (1958); Katz v. United States, 389 U.S. 347, 357 (1967). 
In determining the validity of any warrantless search, the Supreme Court applies a balancing test to weigh the citizen's interest in freedom from arbitrary invasion against the state's interest in safe and effective law enforcement. ${ }^{5}$ For example, where there is no time to get a warrant without unreasonably jeopardizing safety or permitting the destruction of evidence, the Supreme Court deems a warrant unnecessary under the doctrine of exigent circumstances. Applying this doctrine, the Court has approved few searches, and only under the following conditions: hot pursuit of a fleeing felon, ${ }^{6}$ extinguishing and investigating the causes of a fire, ${ }^{7}$ and evidence in the process of natural deterioration. ${ }^{8} \mathrm{~A}$ second, more narrow exception to the warrant requirement is invoked where the search is considered "reasonable," in part because the search is so limited in time and scope that the warrant and probable cause requirements may be waived altogether. ${ }^{2}$ These two principles, exigent circumstances and limited searches, may justify police efforts to control hidden third parties by means of protective sweeps.

Although the purpose of the protective sweep is not to uncover evidence, but rather to locate people who might jeopardize public safety $^{10}$ or destroy evidence, the plain view doctrine would allow the admission of any evidence discovered in plain view during the course of the sweep. ${ }^{11}$ To preserve the privacy of the home in the face of this possibility, some lower courts have insisted that the sweep be strictly limited in time and depth, stressing that the search is cursory and preventive in nature. As the Supreme Court has explained, "the scope of a warrantless search must be commensurate with the rationale that excepts the search from the warrant requirement."12 Enforcing this principle, the courts apply the ex-

s Camara v. Municipal Court, 387 U.S. 523, 536-37 (1967).

- See, for example, Warden v. Hayden, 387 U.S. 294 (1967).

' See, for example, Michigan v. Tyler, 436 U.S. 499, 509 (1978).

See, for example, Schmerber v. California, 384 U.S. 757, 770-71 (1966) (blood alcohol test); Cupp v. Murphy, 412 U.S. 291 (1973) (fingernail scrapings).

- See, for example, Terry v. Ohio, 392 U.S. 1 (1968) (requiring only reasonable suspicion that person is armed and dangerous prior to stopping and frisking him); Chimel v. California, 395 U.S. 752 (1969) (requiring probable cause to arrest, but not requiring probable cause to search the grabbing area of the arrestee).

${ }^{10}$ The phrases "threats to police" and "threats to public safety" are used interchangeably in this comment.

${ }^{11}$ In Harris v. United States, 390 U.S. 234, 236 (1968), the Supreme Court reiterated: "It has long been settled that objects falling in the plain view of an officer who has a right to be in the position to have that view are subject to seizure and may be introduced in evidence." If the protective sweep is lawful, then any evidence discovered in open view during the sweep is admissible at trial.

12 Murphy, 412 U.S. at 295 (footnote omitted). 
clusionary rule ${ }^{13}$ to bar the admission of evidence which officers would not have discovered had they been looking only for people. ${ }^{14}$

Given exigent circumstances and a limited search, it would be unreasonable to require the police to obtain a search warrant if that would expose the officers and the public to unnecessary harm, or would cause the irrevocable loss of evidence. Lower courts thus consider the protective sweep to be a relatively minimal additional intrusion on the arrestee's privacy in comparison to the public interest in safe and effective law enforcement. But the courts are not in agreement over the degree of urgency necessary to support a protective sweep. As a result, arresting officers have no guidance as to when they may lawfully initiate a protective sweep.

This comment aims to resolve this confusion. In Section $I$, the comment surveys the Supreme Court decisions which bear on protective sweeps. Section II will then examine the circuit courts' varying interpretations of the Supreme Court's dicta, and will point out the circuit courts' general confusion over use of the protective sweep. Finally, Section III will compare two alternative protective sweep models, one that adopts a bright-line rule authorizing protective sweeps incident to all arrests within the arrestee's premises, and another that requires individual findings of cause to search.

\section{The Supreme Court's Dicta: Discerning The Criteria For A Constitutional Protective Sweep}

The Supreme Court has never squarely defined the concept of a protective sweep, or indicated under what circumstances such a cursory search might be constitutional. However, two lines of the Court's reasoning support the lower courts' introduction of a protective sweep exception to the warrant requirement: the exception for limited searches and the exception for exigent circumstances. These are overlapping and interwoven principles which require some untangling.

\section{A. The Limited Search Incident To Arrest}

Although no Supreme Court decision has upheld a warrantless

13 Although the Constitution does not require the exclusionary rule, see United States v. Leon, 468 U.S. 897, 905-06 (1984), the Supreme Court will not allow evidence which is the product of an unconstitutional search or seizure to be admitted at trial. See Weeks v. United States, 232 U.S. 383, 398 (1914). The rule is intended to deter unlawful police conduct, see Linkletter v. Walker, 381 U.S. 618,633 (1965), and to promote the integrity of the judicial system, see Elkins v. United States, 364 U.S. 206, 222-23 (1960).

14 See United States v. Kolodziej, 706 F.2d. 590, 597 n.2 (5th Cir. 1983). 
search solely because it was limited in time or depth, the finding that the search was no more intrusive than necessary often has been decisive in upholding searches. The two seminal cases in the category of minimally intrusive searches are Chimel $v$. California ${ }^{15}$ and Terry $v$. Ohio. ${ }^{16}$

Before Chimel, most courts, relying on Harris v. United States ${ }^{17}$ and United States $v$. Rabinowitz, ${ }^{18}$ permitted thorough warrantless searches of a home incident to any lawful arrest therein. In Harris, police lawfully arrested the defendant in his living room on charges of check forging, whereupon they extensively searched his entire apartment for more checks. The Court sustained the search because it was "incident to arrest." 19 Similarly', in Rabinowitz the Court upheld the warrantless search of Rabinowitz's office because the police had arrested him on the premises: "[There is a right] to search the place where the arrest is made in order to find and seize things connected with the crime. . . ."20 These cases produced a now defunct doctrine known as the HarrisRabinowitz rule.

In 1969, the Supreme Court in Chimel radically restricted the scope of permissible searches incident to arrest. In that case, police had a warrant to arrest Chimel for allegedly robbing a coin shop, but did not have a warrant to search his home. After arresting Chimel, the officers meticulously searched his entire three bedroom home for stolen coins. Although the Court struck down the search, it held that

it is entirely reasonable for the arresting officer to search for and seize any evidence on the arrestee's person in order to prevent its concealment or destruction. And the area into which an arrestee might reach in order to grab a weapon or evidentiary items must, of course, be governed by a like rule. ... There is ample justification therefore, for a search of the arrestee's person and the area "within his immediate control"-construing that phrase to mean the area from within which he might gain possession of weapon or destructible evidence. ${ }^{21}$

\footnotetext{
15395 U.S. 752 (1969).

26 392 U.S. 1 (1968).

17331 U.S. 145 (1947).

18339 U.S. 56 (1950).

19 Harris, 331 U.S. at 151-52.

20 Rabinowitz, 339 U.S. at 61, quoting Agnello v. United States, 269 U.S. 20,30 (1925).

21 Chimel, 395 U.S. at 763.
} 
Chimel thus authorized searches of the area within the grabbing reach of the arrestee, while barring those routine searches of the entire premises incident to arrest which were once sanctioned by the Harris-Rabinowitz rule.

At first glance, Chimel appears to foreclose any search of the premises beyond the arrestee's immediate control. But while the opinion defines the relationship of the arresting officer to the apprehended suspect, it fails to consider the threat posed by a third party on the premises who could have a weapon or who could conceal or destroy evidence. The Court noted that "[a] gun on a table or in a drawer in front of one who is arrested can be as dangerous to the arresting officer as one concealed in the clothing of the person arrested," "22 but it did not discuss the danger posed by a gun in the hands of a confederate in the corner room. Then, if one were to extend Chimel's logic, one could justify a limited protective sweep incident to arrest for people who pose risks comparable to those posed by the arrestee: a gun in the hands of a confederate is arguably as dangerous to an arresting officer as a gun concealed in the arrestee's clothing.

There are other instances besides Chimel where the Court has authorized limited searches in order to protect public safety. In the context of investigative stops, the Court has upheld a limited warrantless search to prevent harm to an officer where the officer has a reasonable basis for suspecting that a person whom the officer has stopped is armed and dangerous. In Terry $v$. Ohio, ${ }^{23}$ the defendant aroused a police officer's suspicions by apparently "casing" a store for a robbery. When the policeman stopped the defendant to question him and received no coherent response, the officer frisked the defendant and discovered a pistol in his pocket. The defendant objected to the patdown, arguing that the officer lacked probable cause to arrest or search him.

Upholding the frisk, the Court indicated that the parameters of a search determine, in part, the search's constitutionality. Here, the search was no broader than necessary to find weapons: "[The officer] did not conduct a general exploratory search for whatever evidence of criminal activity he might find;" he merely patted down the outer clothing of the defendant. ${ }^{24}$ Thus, the more superficial the invasion, the more likely the Court is to uphold the

\footnotetext{
22 Id. at 763.

23392 U.S. 1 (1968).

24 Id. at 29,30 .
} 
search. ${ }^{25}$ Like the search in Terry, the protective sweep is no more intrusive than necessary to achieve its preventative purposes.

\section{B. Exigent Circumstances}

1. The Threatened Destruction of Evidence. Dicta in several Supreme Court decisions suggest that in certain exceptional circumstances, the threatened destruction of evidence, coupled with probable cause, provides a legitimate basis for foregoing the warrant requirement. For example, in Johnson v. United States, the Court found a search unconstitutional because there were no exceptional circumstances in the case and "[n]o reason [was] offered for not obtaining a search warrant except the inconvenience to the officers." anating from Johnson's hotel room, but did not assert that "evidence or contraband was threatened with removal or destruction."27 In a somewhat more recent case, Schmerber $v$. California, the Court upheld a warrantless blood alcohol test performed on a clearly intoxicated man. Here the police officer "might reasonably have believed that he was confronted with an emergency, in which the delay necessary to obtain a warrant under the circumstances threatened 'the destruction of evidence. . . ." "m28

In Chimel, the dissenters, Justices White and Black, argued in favor of a broad "search incident to arrest" exception to the warrant requirement. Justice White contended that

assuming that there is probable cause to search premises at the spot where a suspect is arrested, it seems to me unreasonable to require the police to leave the scene in order to obtain

\footnotetext{
${ }^{23}$ See also Murphy, 412 U.S. at 296 (noting limited nature of taking scrapings from fingernails).

28333 U.S. 10, 15 (1948).

${ }^{27}$ Id. Similarly, in McDonald v. United States, 335 U.S. 451, 455 (1948), the Court did not face a situation where "property [was] in the process of destruction" or was "likely to be destroyed." Comparable language was used in United States v. Jeffers, where the Court found there to be "no question of. . . imminent destruction, removal or concealment of the property intended to be seized." 342 U.S. 48,52 (1951). In Jeffers, police officers entered and searched a hotel room rented by Jeffers' aunts. The officers did not have a search or arrest warrant. The aunts were absent, there were no exceptional circumstances, and the officers could have prevented any destruction of evidence by merely guarding the door. By negative implication, the decision suggests that destruction of evidence could, in some circumstances, excuse the failure to obtain a warrant.

${ }^{28} 384$ U.S. at 770 (citations omitted). See also Murphy, 412 U.S. at 296, where police had probable cause to believe that a suspected strangler had blood under his fingernails. These circumstances "justified the police in subjecting him to the very limited search necessary to preserve the highly evanescent evidence they found under his fingernails."
} 
a search warrant when they are already legally there to make a valid arrest, and when there must almost always be a strong possibility that confederates of the arrested man will in the meanwhile remove the items for which the police have probable cause to search.

Justice White thus asserted that an arrest, based on probable cause, almost always creates the potential for loss of evidence, and therefore presumptively produces exigent circumstances justifying a warrantless search. ${ }^{29}$ Under this line of analysis, the protective sweep, as it is incident to an arrest based on probable cause, would be per se constitutional.

The Court rejected Justice White's argument in Vale v. Louisiana. ${ }^{30}$ There, the police had placed Donald Vale's house under surveillance and had obtained a warrant for his arrest on suspicion of trafficking narcotics. After observing an apparent exchange of narcotics between a known addict and Vale outside the house, the officers arrested Vale on his front steps. Without a warrant, the police then conducted a cursory search of Vale's home to see if a third party was present. ${ }^{31}$ While the police did so, Vale's mother and brother returned to the house. Still lacking a warrant, the law enforcement agents then conducted a full-scale search which uncovered narcotics in Donald Vale's bedroom.

The Vale court declined the opportunity to expand Chimel's grabbing area exception to include all searches for third parties incident to an arrest. ${ }^{32}$ Justice Stewart, author of both the Vale and Chimel majority opinions, asserted that the police could have obtained a search warrant in Vale at the same time that they applied for the arrest warrant. Thus, the majority "decline[d] to hold that an arrest on the street can provide its own 'exigent circumstance' so as to justify a warrantless search of the arrestee's house." ${ }^{33}$ The opinion did not explicitly deal with the concern that Donald Vale's mother and brother might have destroyed the evidence if the po-

\footnotetext{
${ }^{29}$ Chimel, 395 U.S. at 774, 781 (White dissenting).

${ }^{30} 399$ U.S. 30 (1970).

31 Vale did not object to this search because it uncovered no evidence.

${ }^{32}$ The Court characterized the Chimel "search incident to arrest" rationale as follows: A search may be incident to an arrest "only if it is substantially contemporaneous with the arrest and is confined to the immediate vicinity of the arrest."'. . . If a search of a house is to be upheld as incident to an arrest, that arrest must take place inside the house,. . not somewhere outside-whether two blocks away,...twenty feet away,. . .or on the sidewalk near the front steps.
}

Id. at 33-34 (citations omitted).

${ }^{33}$ Id. at 35. 
lice had withdrawn to obtain a search warrant. But by invalidating the search, the Court implicitly decided that the abstract threat of destruction of evidence by third persons could not justify a warrantless search. Further, the Court's assertion that an arrest outside a house cannot justify a warrantless inside-the-house search incident to arrest indicates that the Court hesitates to extend the Chimel rationale to all threats to evidence. ${ }^{34}$

Vale did imply, however, that a warrantless search would be valid if the evidence ultimately seized had been "in the process of destruction" or was "about to be removed from the jurisdiction" at the initiation of the search. ${ }^{35}$ The Court would uphold a warrantless search under these compelling circumstances as particular facts justified, but not as a result of a presumption about exigencies stemming from an arrest. Thus, where there is only a possibility that accomplices might destroy or remove evidence, a search of a home is not valid merely because there has been an arrest outside. But Vale left open the question whether the protective sweep would be authorized where there has been an arrest inside the arrestee's home.

Regardless of where the arrest took place, Justice Black and Chief Justice Burger would have upheld the protective sweep in Vale. Both Justices considered the police actions to be reasonable in light of the substantial possibility that Donald Vale's mother and brother would have destroyed the evidence if the police had left to obtain a search warrant. ${ }^{36}$ The Vale dissenters construed the abstract danger of destruction of evidence to be an exceptional circumstance justifying a warrantless search whether the arrest was inside or outside the premises.

2. Protecting the Safety of the Arresting Officer. Another line of Supreme Court decisions upholds warrantless arrests and cursory searches carried out in order to protect the safety of the arresting officers. In balancing the privacy interests protected by the fourth amendment against the risk of physical harm to law enforcement officers, the Supreme Court defers to the reasonable beliefs of police officers that they can avoid injury through a warrantless search. Moreover, the Court has explicitly held that the police

s4 The Court pointed out that because the arrest took place outside the house, even the pre-Chimel Harris-Rabinowitz rule would not cover the search. Id. at 33.

35 "The officers were not responding to an emergency. . . . They were not in hot pursuit of a fleeing felon. ... The goods ultimately seized were not in the process of destruction. ... Nor were they about to be removed from the jurisdiction." Id. at 35 (citations omitted).

36 See id. at 38 (Black dissenting). 
need not make the usual showing of probable cause to search where officer safety is endangered and where the intrusion is minimal.

The Court set forth these principles in Terry. The majority found that a frisk could be constitutionally permissible despite the lack of probable cause for either a full arrest or a full search. ${ }^{37}$ The Court did not rely upon the traditional exigent circumstances exception to the warrant requirement, which requires a showing of probable cause. Rather, the Court waived the warrant requirement altogether because the search was only a "frisk" and because the risks to the officer were substantial. The Court's inquiry was thus only into reasonableness, not probable cause. ${ }^{38}$ As long as an officer can articulate grounds for initiating the patdown-that is, for believing that the suspect is armed and dangerous-his actions are constitutional. ${ }^{39}$ The desire to protect the officer from physical harm outweighs the intrusion on a citizen's privacy.

Other cases in which the Court has granted police officers the right to search a limited area to protect their safety include Chimel,,$^{40}$ allowing searches of the grabbing area; United States $v$. Robinson, ${ }^{41}$ authorizing a search of the person of the arrestee incident to any lawful arrest; and New York v. Belton, ${ }^{42}$ upholding searches of the interior of a car. Although other factors in these cases contributed to the Court's finding the searches constitutional, these opinions show the Court's strong interest in protecting the police against dangerous suspects. Regardless of whether a police officer has probable cause to search the targeted area, she

s7 The Court stressed both that the search resulted from the officer's justifiable fears that the defendant might be armed and that the officer's safety might be threatened, and also that the search was no more intrusive than necessary to uncover weapons. See 392 U.S. at $27-30$.

ss This distinction is important because it is easier for police to show reasonableness than it is for police to show probable cause. For a discussion of the factors needed for a showing of reasonableness in the context of sweeps, see notes 104-08 and accompanying text. For a discussion of probable cause in this context, see notes 116-19 and accompanying text.

ss The Court said,

[I]n determining whether the officer acted reasonably in such circumstances, due weight must be given, not to his inchoate and unparticularized suspicion or 'hunch,' but to the specific reasonable inferences which he is entitled to draw from the facts in light of his experience.

Terry, 392 U.S. at 27.

10395 U.S. at 752.

41414 U.S. 218 (1973).

12453 U.S. 454 (1981). 
may do so to ensure her safety. ${ }^{43}$

Yet absent a showing of potential danger, the Court has not allowed searches of persons incident to the lawful arrest of other persons. In Ybarra v. Illinois, the police had an arrest warrant for a bartender suspected of dealing heroin and a search warrant for his bar. While arresting the bartender, the police frisked all of the patrons of the bar, including Ybarra, even though the officers had no reason to suspect that any of the patrons were armed and dangerous. In spite of the warrants to search the bar and arrest the bartender, the Court declined to admit into evidence packages of heroin found on Ybarra when he was searched. ${ }^{44}$ Thus it is important to keep in mind that even if police perform a constitutional protective sweep, they must have some articulable grounds for believing that a person discovered in the sweep is armed and dangerous before they can frisk that person, unless that person is already subject to lawful arrest.

\section{The Court and the Sweep}

To date, the Court's only direct treatment of the protective sweep is in Justices Brennan, White and Marshall's dissent from denial of certiorari in Vasquez $v$. United States, ${ }^{45}$ a Second Circuit case upholding a protective sweep. The case involved an arrest outside the suspect's apartment building, while the police believed that third parties in the apartment might destroy evidence. Thus prompted to enter the building without a warrant, the police dis-

4s This is not to suggest that searches occur at will: Chimel requires probable cause to arrest as a predicate to a grabbing area search; Terry requires reasonable suspicion that the suspect is armed and dangerous; and both Robinson and Belton require both that probable cause to arrest exist and that the arrest be custodial.

1444 U.S. 85 (1979). The question confronting the Court was whether the application of Ill.Rev.Stat. ch.38, § 108-9 (1975) to the facts of the case violated the fourth and fourteenth amendments. The statute provides:

In the execution of the warrant the person executing the same may reasonably detain to search any person in the place at the time:

(a) To protect himself from attack, or

(b) To prevent the disposal or concealment of any instruments, articles or things particularly described in the warrant.

The Court held that the law "falls within the category of statutes purporting to authorize searches without probable cause, which the Court has not hesitated to hold invalid as authority for unconstitutional searches." Ybarra, 444 U.S. at 96 n.11. While the Illinois statute did not explicitly authorize protective sweeps-presumably, officers would have had to obtain custody of the other individuals by some other means before turning to $\S 108-9$ 's rules governing these detentions-it is instructive that the Court did not read into the arrest context a per se rule of exigency, which the dissent pressed. See id. at 96-98 (Burger dissenting); id. at 107-08 (Rehnquist dissenting).

45638 F.2d 507 (2d Cir. 1980), cert. denied, 454 U.S. 975 (1981). 
covered contraband in the suspect's apartment. The Justices believed Vasquez presented an unreasonable exception to the warrant requirement, as its sweep doctrine

would allow warrantless entry into a home following an arrest outside, if the arresting officers possess a reasonable belief that third persons are inside and aware of the arrest, "so that they might destroy evidence." The exception thus stated not only authorized the police to enter a home without a warrant in circumstances far less compelling than we have recognized, but permits law officers, in determining the time and manner of executing an arrest, to contrive their own exigency and thereby avoid the necessity of procuring a warrant before entering the home. ${ }^{48}$

The Justices also objected to the lack of probable cause. ${ }^{47}$ In their view, a search based on "nothing more than the officers' 'reasonable belief' that there were additional persons in the apartment who were aware of [Vasquez's] arrest" was an unreasonable warrantless invasion of the premises. The dissenters concluded, "[d]espite the currency of the doctrine in the lower courts, no decision of this Court supports the existence of a general 'security check' exception to the warrant requirement."48

\section{Inconsistent Treatment of the Protective Sweep By The Circuit Courts}

The protective sweep doctrine is young. Before the Chimel decision in 1969, the courts never confronted the issue of whether police could sweep the premises for third parties who might destroy evidence or harm the arresting officers. Under the HarrisRabinowitz rule, police had authority to conduct a full-scale search of the entire premises incident to any lawful arrest therein. The Supreme Court's Chimel decision, however, limited the search inci-

46 Vasquez, 454 U.S. at 983 (Brennan dissenting from denial of certiorari). Justice Brennan's dissent prompted a response from Justice Stevens, who argued that Brennan's characterization of the lower court's opinion was not fair. See id. at 977 n.4.

${ }^{47}$ It is noteworthy that Justice White concurred with the Brennan dissent, particularly since Justice White's Chimel dissent had argued that every arrest creates exigent circumstances sufficient to justify a warrantless search. This suggests either that Justice White's views have changed, or that the cases are distinguishable (Chimel's arrest was inside, whereas Vasquez's was outside), or that White simply thinks the Court should have granted certiorari. The last alternative seems least likely because White could have dissented from the denial of certiorari without joining the Brennan opinion.

48 Id. at 987. 
dent to arrest to the arrestee's grabbing area, and, in response, the lower courts created the protective sweep exception to redress the difficulties imposed by the warrant requirement in situations where third parties pose an immediate threat to law enforcement.

Although the protective sweep exception is widely established, it is not well-delineated. From circuit to circuit, there is no consistent or meaningful standard to distinguish between a valid and an unlawful sweep. As the Ninth Circuit observed in United States $v$. Wiga, "[w]hile nearly all of our fellow circuits have endorsed [protective sweeps], there is considerable disagreement over the degree of reasonable suspicion necessary to justify a sweep of the premises." Until the Supreme Court rules on the protective sweep, the lower courts are left largely without guidance.

\section{A. Sweeps to Preserve Evidence}

With respect to the evidentiary prong of the sweep, circuits have adopted various standards for judging between valid and invalid searches. These standards range along a continuum from requiring certain destruction of evidence to accepting an abstract threat of destruction, absent even probable cause to search for the evidence.

In validating protective sweeps, the Fifth, Sixth and Ninth Circuits apply a pragmatic "now or never" standard. Under this rule, where a police officer has probable cause to search for evidence but believes the evidence will be lost if she abandons her search to obtain a warrant, the courts consider an immediate, limited search for people capable of destroying the evidence permissible under the fourth amendment.

Operating under this standard, the Sixth Circuit in United States $v$. Elkins approved a protective sweep of the arrestee Elkins' premises conducted after a police officer witnessed Elkins' girlfriend dump cocaine into a commode. The court elaborated,

warrantless entry will be sustained when the circumstances then extant were such as to lead a person of reasonable caution to conclude that evidence of a federal crime would probably be found on the premises and also that such evidence would probably be destroyed within the time necessary to obtain a search warrant. ${ }^{.0}$

10 662 F.2d 1325, 1330 (9th Cir. 1981).

so 732 F.2d 1280, 1284 (6th Cir. 1984). See also United States v. Adamo, 742 F.2d 927, 948 (6th Cir. 1984), in which the court held that police officers could: 
The court upheld the sweep of Elkins' entire home.

The Ninth Circuit likewise considers a protective sweep justifiable only "[w] hen police officers, acting on probable cause and in good faith reasonably believe from the totality of the circumstances that. . evidence or contraband will imminently be destroyed."'In In United States $v$. Driver, the government argued that the police had probable cause to believe that heroin smugglers, one of whom was Driver, had detected their undercover investigation; however, there were no facts to support this contention. Rather, according to the court, the smugglers had not suspected that there was an informant present, they were not behaving unusually, and the police had had ample time to obtain a search warrant. The Ninth Circuit thus held that the assumptions about the likelihood of imminent destruction of the evidence were too speculative to justify the warrantless entry. ${ }^{62}$

The First and Seventh Circuits endorse a slightly weaker standard: probable cause to search coupled with a substantial risk of destruction of evidence. As the First Circuit set forth in United States $v$. Veillette, so long as police officers have probable cause to search, and they also believe that there is a "great likelihood" of destruction of evidence, then they may forego the warrant requirement. ${ }^{53}$ The court did not uphold the Veillette sweep because the

conclude reasonably that [a confederate] had returned from Florida that every [sic] day with a quantity of cocaine and was in the process of distributing it to the known narcotics traffickers and others entering and exiting his apartment. The conclusion that evidence, that is, cocaine, was actually being 'lost' through distribution before their very eyes justified the officer's belief that exigent circumstances existed.

${ }^{31}$ United States v. Driver, 776 F.2d 807, 810 (9th Cir. 1985) (emphasis added), citing United States v. Kunkler, 679 F.2d 187, 191-92 (9th Cir. 1982). For other Ninth Circuit examples see United States v. Wulferdinger, 782 F.2d 1473, 1476 (9th Cir. 1986) (allowing a warrantless search only if there was probable cause to believe that occupants would destroy evidence before a search warrant could be obtained); United States v. Hicks, 752 F.2d 379, 383-84 (9th Cir. 1985) ("there was probable cause to believe that there were persons within the Hicks residence who would destroy. . .cocaine" left on the premises); United States v. Johnson, 660 F.2d 749, 752 (9th Cir. 1981), quoting United States v. Gardner, 627 F.2d 906, 909 (9th Cir. 1980) ("Exigent circumstances are those in which a substantial risk of harm to the persons involved or to the law enforcement process would arise if the police were to delay a search until a warrant could be obtained"); United States v. Hackett, 638 F.2d 1179, 1182-86 (9th Cir. 1980) (warrantless sweep of premises valid after narcotics dealer's discovery of transmitter concealed in contraband).

The Fifth Circuit also applies a "now or never" standard. See United States v. Thompson, 700 F.2d 944, 947-49 (5th Cir. 1983).

s2 Driver, 776 F.2d at 811.

The Fifth Circuit has invalidated searches on the same grounds. See United States v. Congote, 656 F.2d 971, $974 \mathrm{n} .2$ (5th Cir. 1981) (mere possibility of the destruction of evidence does not qualify as an exigent circumstance).

ss United States v. Veillette, 778 F.2d 899, 902 (1st Cir. 1985). See also United States v. 
district court had merely "speculated on various possibilities that might have given the police 'reason to believe' that exigent circumstances existed." A4 Although the court admitted the seized evidence on other grounds, ${ }^{55}$ the case indicates that the First Circuit will validate a protective sweep only if officers can demonstrate a great likelihood that evidence will be destroyed.

The decisions above rest on a showing of probable cause plus a degree of certainty that evidence would be, as opposed to might be, destroyed if the police officer had to obtain a warrant. Other circuits impose less rigorous fourth amendment constraints on arresting officers. For example, the Fourth Circuit has found that "when officers have probable cause to believe that contraband is present, and, in addition, they reasonably believe that the evidence may be destroyed or removed before they can secure a search warrant, a warrantless entry is justified." ${ }^{\circ 6}$ Unlike the First, Fifth, Sixth, Seventh, and Ninth Circuits, the Fourth Circuit does not require law enforcement officers to show that evidence will probably be destroyed, only that it may be destroyed. The Second and Tenth Circuits have adopted this same position. ${ }^{\text {s7 }}$

Moore, 790 F.2d 13, 15 (1st Cir. 1986) (upholding a warrantless search based upon a high risk that a confederate would flee or destroy evidence when a recently arrested dealer did not return with the proceeds from a narcotics transaction; "exigent circumstances exist when government agents reasonably believe that evidence will be destroyed or a suspect will flee if an immediate entry is not made"); United States v. Baldacchino, 762 F.2d 170, 176-78 (1st Cir. 1985) (employing great likelihood standard).

For examples from the Seventh Circuit, see United States v. Napue, 834 F.2d 1311 (7th Cir. 1987) ("Exigent circumstances exist where the police have an objective and reasonable fear that evidence is about to be destroyed"); United States v. Altman, 797 F.2d 514, 515 (7th Cir. 1986) (upholding a protective sweep based upon the "serious risk that evidence would be destroyed").

s4 Veillette, 778 F.2d at 903.

ss See id. at 903-04.

B6 United States v. Turner, 650 F.2d 526, 528 (4th Cir. 1981) (emphasis added).

${ }^{57}$ For examples from the Second Circuit, see United States v. Martino, 664 F.2d 860, 869 (2d Cir. 1981) (where "officers had a legitimate basis for believing there were other persons inside the apartment who were likely to be aware of the arrest and therefore might destroy evidence in the apartment, a warrantless entry into, and security check of the apartment [was] permissible") (emphasis added); Vasquez, 638 F.2d at 531 (authorizing protective sweeps where officers have reason to believe that third persons were aware of an arrest outside the premises and that they might destroy evidence).

For examples from the Tenth Circuit, see United States v. Mabry, 809 F.2d 671, 678-80 (10th Cir. 1987) (upholding sweeps based upon probable cause and exigent circumstances; exigent circumstances include situations where drug dealers might destroy evidence if their runners do not return from drug sale promptly); United States v. Cuaron, 700 F.2d 582, 586 (10th Cir. 1983) ("When officers have reason to believe that criminal evidence may be destroyed,. . .or removed,. . . before a warrant can be obtained, the circumstances are considered sufficiently critical to permit [a warrantless sweep].”)(emphasis added). 


\section{B. Protective Sweeps For Safety}

Safety sweeps address a different and more severe threat than evidentiary sweeps, and therefore safety searches often require a lesser quantum of certainty before they may be lawfully initiated. ${ }^{.8}$ Some courts, relying on Terry, apply a reasonable suspicion test, wherein police officers need only demonstrate grounds to suspect that third parties on the property might imperil public safety. As the Tenth Circuit explained in United States $v$. Owens, " '[w]hen officers have arrested a person inside his residence, the exigent circumstances exception permits a protective search of part or all of the residence when the officers reasonably believe that there might be other persons on the premises who could pose some danger to them." "ס8 Although the officer's suspicions must be based upon objective articulable facts, these facts generally are not hard to show. ${ }^{60}$ Where police officer safety is thought to be in jeopardy, courts frequently uphold a protective sweep on a lesser showing of certainty than that required when officers engage in protective sweeps in order to protect evidence.

Even in the context of officer safety, however, some courts require a higher showing of exigency than a mere reasonable suspicion of the presence of a third person. In United States $v$. Kolodziej, for example, the Fifth Circuit concluded, "[a] cursory safety check is permissible 'when the circumstances provide, at the

${ }^{88}$ For example, see the dissenting opinion in Cuaron, 700 F.2d at 592 and n.3 (Kelly dissenting) ("reason to believe" test is too speculative for exigencies relating to preservation of evidence, but it might be appropriate in the officer safety context).

${ }^{59} 782$ F.2d 146, 151 (10th Cir. 1986), quoting United States v. Riccio, 726 F.2d 638, 641 (10th Cir. 1984). The court found, however, that the only person suspected to be present on the premises, a sleeping naked woman, posed no reasonable danger to the armed officers.

${ }^{60}$ See, for example, United States v. Valles-Valencia, 811 F.2d 1232, 1236 (9th Cir. 1987) (neighbor's report about third parties in area, along with the belief that these suspects were armed, gave officers reasonable belief they might be in danger); United States v. Standridge, 810 F.2d 1034, 1037 (11th Cir. 1987) (upholding sweep following arrest of armed and dangerous bank robber "so long as there is uncertainty as to whether there might be others present"); United States v. Bernard, 757 F.2d 1439 (4th Cir. 1985) (reasonable suspiscion that conspirator was present in marijuana fields after police helicopter surveillance spotted a third adult who was unaccounted for); United States v. Irizarry, 673 F.2d 554, 558 (1st Cir. 1982) (reasonable suspicion that fourth person was present in hotel room after three others, one of whom was armed, had emerged from it); United States v. Bruton, 647 F.2d 818, 82223 (8th Cir. 1981) (finding reasonable suspicion based on Bruton's previous conviction for illegal possession of firearms, and a belief that some of his confederates may have been in the vicinity). The Bruton dissent points out, however, that the majority failed to consider that the policemen did not assume positions of safety, but actually had gathered around a window of Bruton's trailer. This suggested to the dissent that the officers did not fear an armed accomplice within. See id. at 829 (Lay concurring and dissenting).

See also the cases cited in United States v. Hill, 730 F.2d 1163, 1169-70 (8th Cir. 1984). 
least, probable cause to believe that a serious threat to safety is presented." " Arresting officers "must 'have reasonable grounds to believe that there are other persons present inside who might present a security risk." "61 Relying on Kolodziej, the Sixth Circuit has required the "government [to] show that there was 'a serious and demonstrable potentiality for danger" "62 before upholding a warrantless search.

\section{Confusion Within The Lower Courts}

The above discussion demonstrates that the circuits disagree about what constitutes legitimate grounds to uphold a protective sweep in the context both of preserving evidence and of protecting officer safety. ${ }^{63}$ Worse yet, individual circuits jumble the doctrines by using safety standards in evidence cases, treating safety and evidentiary sweeps alike, or announcing standards but not applying them correctly to the facts at hand. It is particularly troubling to find conflicting standards within a single decision. When an opinion proffers several incongruent criteria for justifying a protective sweep, it fails to serve as a coherent guide to police officers. The recent decision in United States $v$. Jones ${ }^{84}$ demonstrates the point. From inside their hotel room, Jones and Nisbet had attempted to resist the police. During the struggle one of them fired a shotgun. After arresting them, the police searched the adjoining rooms for

61706 F.2d at 597, 596 quoting United States v. Cravero, 545 F.2d 406, 418 (5th Cir. 1976) and United States v. Sheikh, 654 F.2d 1057, 1071 (5th Cir. 1981).

${ }^{62}$ United States v. Morgan, 743 F.2d 1158, 1163 (6th Cir. 1984), quoting Kolodziej, 706 F.2d at 596. The police officers in Morgan were on the trail of the defendant after he had been target shooting in a public park. But because the police could not show that Morgan represented "an immediate threat to the arresting officers or the public," the court disallowed a warrantless search of Morgan's residence following his arrest outside. Morgan, 743 F.2d at 1162-63.

For a case applying looser language but reaching the same result, see United States v. Hatcher, 680 F.2d 438, 444 (6th Cir. 1982).

es To add yet another standard, albeit one not yet applied to protective sweeps, a few decisions have introduced the concept of "mild exigency" to authorize an arresting officer to enter a premises without waiting for a response to her knock on the door. When police have knocked and properly announced their identity and purpose, mild exigency justifies simultaneous entry when entry can be accomplished without destruction of property. "Mild exigency may exist where there is a likelihood that the occupants will try to escape, resist or destroy evidence." United States v. McConney, 728 F.2d 1195, 1206 (9th Cir. 1984) (en banc). See also Hicks, 752 F.2d at 383 . This emerging tepid urgency exception presupposes probable cause.

os 696 F.2d 479 (7th Cir. 1982). See also Hicks, 752 F.2d at 384 (upholding sweep, mentioning both "mild exigency" and "probable cause to believe that there was a fair probability that any cocaine in the Hicks' residence would be destroyed in absence of swift action"). 
dangerous persons. The court upheld the sweep as falling within the "boundaries. . .established in Chimel. . .and its progeny." In the court's view, "[t]he police may search adjoining rooms to look for possibly dangerous persons." This would imply that protective sweeps are per se justifiable when incident to arrest. But the court also alluded to the possibility that the protective sweep was not "a search at all" because it was only for people and lasted less than 90 seconds. And finally, the court concluded that protective sweeps are legitimate where "necessary to assure [officer] safety," as determined on a "good reason to believe" basis. ${ }^{65}$

It is similarly difficult to discern a legal framework in opinions which enunciate high standards of exigency without actually applying those criteria to the case at hand. ${ }^{66}$ This practice also defeats the purpose of the exclusionary rule: deterring police misconduct. For example, in United States v. Tabor, the police had obtained a warrant to search Tabor's house for bookmaking paraphernalia, but they had no warrant to search Tabor's unattached barn. After concluding that the state had the burden of proving an

${ }^{65}$ Jones, 696 F.2d at 487 and n.9.

${ }^{68}$ Consider United States v. Muhammad, 658 F.2d 249 (10th Cir. 1981), where the court upheld a warrantless search of the trunk of an alleged bank robber's car on the basis of the officer's suspicions that a dangerous accomplice might be hidden within. The officers conducted this search several hours after impounding the car. The Muhammad dissent bitterly objected:

The police must also have at least reasonable factual grounds for a suspicion that an armed person is hiding in the trunk in order to create the kind of exigency which would justify the by-passing of the Fourth Amendment dictates to permit a warrantless search of the trunk.

The dissent pointed out that the officers did not behave as if they actually feared an armed accomplice within the trunk. Id. at 256 (Murnaghan dissenting).

See also Cuaron, 700 F.2d at 590 (upholding sweep to preserve evidence even though officers had waited one hour before entry); Bruton, $647 \mathrm{~F} .2 \mathrm{~d}$ at 823 (validating a protective sweep based on an officer's "suspicion" that an armed accomplice was nearby; police officer's behavior indicated no fear of attack). The dissent in Bruton commented on the irony of the holding:

Under Steagald [v. United States], [451 U.S. 204 (1981),] officers with a warrant for [a confederate's] arrest could not conduct a warrantless search of [the defendant's] home. They could, however, conduct the same warrantless search simply by asserting a belief that [the confederate] was a dangerous accomplice who might be lurking in [the defendant's] home.

Bruton, 647 F.2d at 830 (Lay concurring and dissenting).

See also United States v. Korman, 614 F.2d 541 (6th Cir. 1980) (holding the following facts significant to validate sweep to prevent the imminent destruction of cocaine: several cars in driveway indicated someone in addition to Korman was home; possibility that Korman used counter-surveillance techniques; evidence easily disposable).

Many of these cases also raise the problems of police-created exigencies and the failure to use telephonic warrants when time permits. For a discussion of these issues, see note 122 and accompanying text. 
exceptional situation meriting a warrantless search of the barn, the court required the officers to show that their suspicions of danger were clear and reasonable: "Officers of the law are not given free reign to conduct sweep searches on the pretense that a dangerous situation might be imminent." Nonetheless, the court validated the warrantless search on the basis of rather innocuous facts: there were miscellaneous cars in the driveway, Tabor owned a revolver, and his dog was "agitated." ${ }^{67}$ It remains unclear what Tabor's legal standard is when the court fails to apply the announced standard to the facts of the case.

Moreover, while purporting to make individual determinations of the need to search, lower courts frequently treat protective sweeps initiated to preserve safety and evidence as identical, although fourth amendment jurisprudence counsels against this confluence. Reasoning that privacy interests are less compelling where life is jeopardized, courts have traditionally interpreted the fourth amendment to require a lesser showing of danger to justify warrantless searches of a home where police officers initiate the search in order to protect officer or public safety rather than to prevent the destruction of evidence. ${ }^{68}$ Nonetheless, many opinions lump the two possible motives for the warrantless search into one undifferentiated category-the protective sweep-as if both bases for the search were of equal urgency. ${ }^{89}$

The consequence of using the same standard in both instances

62722 F.2d 596, 598 (10th Cir. 1983).

68 For further discussion of this topic see Section III-B below.

69 For Second Circuit examples, see Martino, 664 F.2d at 869 ("when law enforcement officers have lawfully entered premises to effect an arrest, they are entitled to make a quick and limited 'security check' of the premises to be sure there are no third persons present who might destroy evidence or pose a safety threat to the officers"); United States v. Segura, 663 F.2d 411, 413 (2d Cir. 1981) (adopting uniform standard authorizing protective sweeps "to ensure that no one else was present who might constitute a threat to [police] safety or destroy evidence"); Vasquez, 638 F.2d at 530 ("When police officers have lawfully entered premises to effect an arrest, they are entitled to make a 'quick and limited pass through the premises to check for third persons who may destroy evidence or pose a threat to officers'" quoting United States v. Gomez, 633 F.2d 999, 1008 (2d Cir. 1980)).

The Ninth Circuit too has articulated a single standard for showings of need for both kinds of sweeps. See, for example, Driver, 776 F.2d at 810; United States v. Alfonso, 759 F.2d 728, 743 (9th Cir. 1984); McConney, 728 F.2d at 1199 (defining "exigent circumstances as those circumstances that would cause a reasonable person to believe that entry (or other relevant prompt action) was necessary to prevent physical harm to the officers or other persons, the destruction of relevant evidence, the escape of the suspect, or some other consequence improperly frustrating legitimate law enforcement efforts"); Kunkler, 679 F.2d at 191-92; Johnson, 660 F.2d at 752.

To the same effect, see Elkins, 732 F.2d at 1284-85; United States v. Blasco, 702 F.2d 1315, 1325-26 (11th Cir. 1983). 
is that protective sweeps for evidence are upheld under a safety standard, instead of being struck down as violating the fourth amendment for insufficient cause to search. When the two standards are coalesced, only the less restrictive one bars intrusive searches. When courts loosely define the law or when they leniently apply nebulous standards to the given facts, the state has the opportunity to fit what would otherwise be an unlawful search into the protective sweep exception.

Perhaps those circuits that treat all protective sweeps alike wish to create a new exception to the warrant requirement based upon the limited search rationale: The Protective Sweep For People, Not Things. Such a bright-line rule would be an extension of the Chimel exception, in that a search only for people would be a reasonable response to the presumptive threats posed by those persons. ${ }^{70}$ The arresting officer would always have a right to look for people, just as she already has the right to search the arrestee's grabbing area.

But if this is what the courts want to accomplish, they are not explicit about it. Rather, their opinions purport to proceed according to traditional individual determinations of need to search. ${ }^{71}$ For example, a Ninth Circuit decision, United States v. Brock, considered exigent circumstances to be present "when there is 'a substantial risk of harm to the persons involved or to the law enforcement process. . .if the police. . .delay a search. ...," Whether out of confusion, convenience, or lack of careful consideration, these circuit courts fail to account for distinctions between safety and evidentiary concerns.

The lower courts' disarray over the treatment of protective sweeps not only demonstrates poor adjudication, but is highly counterproductive. If the courts are responsible for striking the proper balance between privacy and law enforcement, they need to establish clear standards for lawful sweeps, and to enforce the standards through the exclusionary rule. But when the standards are unclear, the exclusionary rule cannot deter offensive police conduct. Faced with uncertain rules, police are left to their intuitive sense of propriety in restraining investigatory impulses. Police of-

${ }^{70}$ One district court decision has employed this reasoning. See United States v. Remy, 658 F.Supp. 661, 668 (S.D.N.Y. 1987): "When police officers have made a lawful arrest, they may make a cursory security sweep of the premises in which the arrest took place."

7 See notes 66-67 and accompanying text.

${ }^{2} 667$ F.2d 1311, 1318 (9th Cir. 1982), quoting United States v. Gardner, 627 F.2d 906, 909 (9th Cir. 1980). 
ficers thus may initiate warrantless searches under less-than-compelling circumstances. ${ }^{73}$

The fourth amendment was designed to interpose a magistrate between the people and the state to guard against precisely these kinds of arbitrary intrusions on privacy. The ambiguities in the law governing protective sweeps call for resolution. The discussion of the preceding sections makes plain several such ambiguities. There is no consensus about whether officers should possess probable cause to believe, or a mere suspicion, that there are third persons on the premises who could endanger the law enforcement process before initiating a sweep. The requisite degree of certainty might depend on whether the risk entails destruction of evidence or a threat to officer safety. Moreover, there is little agreement on whether the threat to destruction of evidence must be imminent or possible. Finally, it is uncertain whether police should be able to conduct a sweep of the premises regardless of whether the justifying arrest has occurred inside the premises, or outside or nearby the premises.

\section{Developing a Coherent Protective Sweep Doctrine}

To resolve the protective sweep debate, one must decide which of two alternatives is better: extension of the Chimel and Terry per se exceptions to the warrant requirement, or individual determinations of exigent circumstances. Both lines of analysis produce a coherent protective sweep doctrine that police could understand and courts could administer. For lawful arrests occurring within the arrestee's premises, the extension of Chimel and Terry results in a bright-line rule granting police the authority to conduct a cursory search incident to arrest for people, not things. On the other hand, application of the traditional exigent circumstance exception calls for a two-prong test, wherein the first step is to determine whether the officers fear that delay will jeopardize their safety or threaten the destruction of evidence. If the concern is for safety, police need only have a reasonable suspicion that an armed and dangerous third party is present. If the concern is for evidence, fourth amendment jurisprudence requires that the police demonstrate probable cause to believe that evidence is in danger of imminent destruc-

${ }^{73}$ On the other hand, without well-delineated principles, police might refrain from conducting a justifiable protective sweep for fear that the trial court will exclude any evidence seized during the check. Although this possibility is remote, nevertheless, public safety could be endangered or the apprehension of criminal suspects could be unreasonably curtailed without clear rules. 
tion. These alternative models give coherence to the protective sweep doctrine. This comment will consider each in greater depth.

A. Extending Chimel and Terry: The Protective Sweep As a Legitimate Search Incident to Arrest

Chimel and Terry serve as a starting point from which to create another bright-line exception to the warrant and probable cause requirement: the protective sweep. In Chimel, the Supreme Court decided that an arrestee has no reasonable expectation of privacy in the area within his immediate control at the time of his arrest. In authorizing a warrantless search of the grabbing area, Chimel did not differentiate between invading privacy for safety or evidentiary reasons. ${ }^{74}$ Hence, Chimel may authorize protective sweeps for people incident to any arrest, sweeps designed either to protect safety or to preserve evidence.

Lower courts have already expanded Chimel's grabbing area beyond an arrestee's reach. For example, in United States v. Patterson, although an arresting officer stood between Patterson and a kitchen shelf six feet away from her, the court considered the shelf to be within her reach. ${ }^{75}$ Likewise, in People $v$. Perry, the court ruled that the police could introduce evidence found in the defendant's desk, even though the handcuffed defendant stood in an adjacent corridor at the time of the search, because the desk was within the defendant's grabbing area at the time of his arrest. ${ }^{76}$ These decisions go far in guarding against dangers posed by the arrestee.

Similarly, Terry provides that police can act to protect themselves against suspicious persons. The Terry Court made clear that police can make a measured response to a suspected threat. ${ }^{77}$ Yet Terry and Chimel do not explicitly address threats created by third persons who might be lurking on the premises. To guard against the risk to the lives of police officers or against the irretrievable loss of evidence, the Court could extend the Chimel and Terry exceptions to take into account the threat created by confederates. After all, a party hidden from the police will often be in a better position to resist the arrest, to harm law enforcers, or to

74 Although safety concerns may have prompted the decision, Chimel allows police to search for and seize any evidence or weapons that are found within the grabbing area of the arrestee. See note 21 and accompanying text.

78447 F.2d 424, 426 (10th Cir. 1971).

${ }^{76} 266$ N.E.2d 330,333 (Ill. 1971).

${ }^{77}$ See notes $23-25$ and accompanying text. 
destroy evidence than the suspect who is already under police control. Like the grabbing area and stop-and-frisk exceptions, the protective sweep exception would seek to prevent persons from destroying evidence or endangering police safety.

One can also justify the sweep exception under Supreme Court decisions which uphold warrantless searches where the invasion of privacy is deemed "minimal" in relation to the need to search. Chimel and Terry demonstrate that the Court will sanction a nomore-intrusive-than-necessary search in order to protect safety. Because the protective sweep is only for people, is cursory, and is conducted only when the police are already lawfully inside the arrestee's premises, it can be considered only an additional minimal invasion. Safety concerns should trump the "slight additional intrusion on [a] defendant['s]. . . privacy, already significantly reduced by his arrest." "rs Further, because the sweep is limited in scope and short in duration, it does not represent the rebirth of the Harris-Rabinowitz rule which permitted a full scale search of the home incident to a lawful arrest.

Neither Chimel nor Terry require arresting officers to have probable cause to search the excepted area. Although Terry requires the officer to possess articulable suspicions before conducting a stop and a frisk, Chimel does not require arresting officers to have even a hunch that the arrestee might be armed or about to destroy evidence. Regardless of whether the police officer has reason to believe that she needs to search immediately, she may search under Chimel's bright-line exception to the warrant requirement in order to provide safety or protect evidence.

In both Terry and Chimel, there were Justices who argued that every arrest presents a risk of danger, and therefore warrantless searches incident to arrests should be presumed reasonable. ${ }^{79}$ Courts might authorize protective sweeps under the same presumption. If officers had to hesitate-either to obtain a warrant, or to determine whether they had a lawful reason to believe evidence might be imminently destroyed, or to consider whether they had reason to suspect that their safety might be endangered-they could lose the opportunity to reduce the risks facing them. ${ }^{80}$ Thus

78 Hatcher, 680 F.2d at 451 (Kennedy dissenting).

79 See Terry, 392 U.S. at 24; Chimel, 395 U.S. at 773 (White dissenting). See also Washington v. Chrisman, 455 U.S. 1, 7 (1982): "Every arrest must be presumed to present a risk of danger to the arresting officer."

so See United States v. Agapito, 620 F.2d 324, 336 (2d Cir. 1980): "The delay attendant upon obtaining a warrant could enable accomplices lurking in another room to destroy evidence. More important, the safety of the arresting officers or members of the public may be 
argued, the sweep is so important that it is a per se reasonable exercise of law enforcement.

In a separate but related context, the Court recently has demonstrated its preference for a per se exception to the warrant requirement for searches incident to arrest. In New York v. Belton, the Court upheld the search of an automobile passenger compartment conducted after arresting officers had removed all of the passengers from the vehicle. After recognizing that the "passenger compartment of an automobile [is] in fact generally, even if not inevitably, within 'the area into which an arrestee might reach in order to grab a weapon or an evidentiary ite[m]," "81 the Court created a bright-line rule: police may search the entire passenger compartment of a car incident to the lawful arrest of any of the passengers within the vehicle.

It may be argued that the Court's conclusion in Belton strains Chimel, in that the Court authorizes searches in areas where no passenger can or could reach. Although the Court's holding is limited to automobile searches, Belton may indicate the Court's desire to provide officers with clear rules even if it must stretch existing doctrine to do so. On the other hand, a number of factors irrelevant to protective sweeps may have influenced the Court's decision in Belton. First, the Court sought to resolve a conflict among many courts over how Chimel related to the so-called automobile exception to the warrant requirement. ${ }^{82}$ Second, any exception relating to cars is inherently narrow and easily confined; thus, cars lend themselves to bright-line rules. ${ }^{83}$ Finally, the Court had recognized previously that privacy interests in a car are less compelling than privacy interests in a home. ${ }^{84}$ Thus the Court's willingness to adopt a bright-line rule for car searches does not necessarily indicate that the Court would favor this approach in the context of private dwellings.

Nonetheless, if the Court were to establish a new exception to the warrant requirement-the Protective Sweep For Persons Exception-the Court then would have to determine when the exception could be applied. In Payton v. New York, the Supreme Court established that, absent exigent circumstances, the police may not

\footnotetext{
jeopardized." (emphasis added).

s1 453 U.S. at 460 , quoting Chimel, 395 U.S. at 763.

${ }^{82}$ See Belton, 453 U.S. at 459, 462 n.6.

${ }^{83}$ For example, in Belton the Court declined to extend its rule to searches of car trunks. See id. at 460 n.4.

84 See Chambers v. Maroney, 399 U.S. 42, 48-51 (1970).
} 
enter a private home to make a warrantless arrest. The Court explained that entry into a private home is an extreme intrusion, and that entry for the purpose of making an arrest is nearly as intrusive as an entry for a search. ${ }^{85}$ Similarly, in Steagald $v$. United States, the Court held that, absent compelling circumstances, the police may not enter one person's private dwelling to arrest a third party, even if the police have an arrest warrant. ${ }^{88}$

Payton and Steagald thus limit the coverage of the would-be protective sweep exception. Unless there are exigent circumstances, a protective sweep would be constitutional only when a person who lives on the premises is arrested in those premises pursuant to a warrant. An arrest with or without a warrant on the front porch, for example, would not support a protective sweep of the house. One can propose numerous permutations, all of which reveal that the supposed bright-line is rather fuzzy. One of the benefits of a clear exception to the warrant requirement is that it serves as a good guide for police. As Justice Stewart notes, it is presumptuous and self-defeating for law makers to create exacting legal standards that are not only difficult for judges to construe in the peace and quiet of their chambers, but virtually impossible for police officers to follow in the volatile environment of the streets. ${ }^{87}$ Further, straightforward rules better serve the deterrence rationale of the exclusionary rule. It makes little sense to exclude evidence on the grounds of an unconstitutional search if the officer, for lack of understanding or time, could not adhere to a complex legal standard. The officer would make the same or a similar mistake again, regardless of whether the court excludes the evidence at trial.

Despite its apparent simplicity, the bright-line protective sweep exception has its own complexities. First, not only will police officers have to remember that, absent exigent circumstances, the exception applies only to arrests within the arrestee's premises, but application of these particulars will produce arbitrary results. An arrest in a doorway can trigger a sweep, for example, whereas an arrest on a porch cannot. The dangers and risks created by hid-

8544 U.S. $573,589-90$ (1980).

${ }^{88} 451$ U.S. 204, 213 (1981).

${ }^{87}$ See Belton, 453 U.S. at 458, 459-60. As Professor LaFave has commented, the fourth amendment should not have " 'all of the character and consistency of a Rorschach blot.' . . [I]t is extremely important that Fourth Amendment doctrine be expressed in terms understandable to the police. . . ." Wayne R. LaFave, The Fourth Amendment in an Imperfect World: On Drawing "Bright Lines" and "Good Faith," 43 U.Pitt.L.Rev. 307, 321, 333 (1982), quoting Anthony G. Amsterdam, Perspectives on the Fourth Amendment, 58 Minn.L.Rev. 349, 375 (1974). 
den third parties in each case, however, will be equal.

Second, the rule would be quite narrow in its operation. There will be many instances where police will not have an arrest warrant, or where the arrest will occur outside a non-arrestee's premises. In these situations, police officers could not rely on the exception, but would have to weigh all of the circumstances-not just the facts of the arrest's location-under traditional fourth amendment criteria to determine whether a protective sweep would be constitutional. The suggested bright-line exception thus may not result in significant administrative savings for the courts or the arresting officers. Both would have to be familiar with two sets of rules. One could propose expanding the sweep exception to encompass warrantless arrests outside of non-arrestees' premises, but that rule would not withstand fourth amendment scrutiny. In Vale, the Court was unwilling to broaden the area which may be searched incident to arrest, perhaps out of a fear that it could not contain such an expansion in future cases. In striking down a protective sweep based on a destruction-of-evidence argument, one court explained, "[t]here is almost always a partisan who might destroy or conceal evidence. Under the government's theory, if a man were arrested in New York, it would be perfectly reasonable to search his home in California to prevent his wife's destruction of evidence." ${ }^{\prime 88}$ The courts have recognized that at some point the distance between the place of the arrest and the place of subsequent search becomes so great that a sweep is unconstitutional. Rather than engage in an endless debate over what that distance is, ${ }^{89}$ the courts seem to have drawn the line at the front door-thus foreclosing the possibility of extending the proposed sweep exception to areas outside the dwelling.

Third, it is important to bear in mind that the "minimal intrusion" of sweeps may not be so minimal after all. Chimel held the practice of routine warrantless searches of the arrestee's premises unconstitutional. Protective sweeps incident to arrest threaten to undermine this decision. To argue that a sweep is only a minimal invasion of privacy assumes the conclusion. Just because a search is not full-scale does not make the invasion less intrusive. ${ }^{90}$

8avis v. United States, 423 F.2d 974, 979 (5th Cir. 1970).

89 See notes 75-76 and accompanying text for a discussion of a similar inability to rationally define "grabbing area" in cases following Chimel.

${ }^{\text {so }}$ A police invasion into the privacy of the home cannot be lightly dismissed as "minimal." "At the very core [of the fourth amendment] stands the right. . .to retreat into [the] home and there be free from unreasonable governmental intrusion." Silverman v. United States, 365 U.S. 505, 511 (1961). The Court in Terry explicitly rejected "the notions that the 
Moreover, it is difficult to argue that a police inspection of every room of a home "just for people" is not invasive. This is a substantial invasion of privacy, and grave consequences may ensue since the protective sweep will operate in conjunction with the plain view doctrine.

Fourth, the jurisprudence of the fourth amendment does not necessarily favor blanket exceptions to the warrant requirement, especially where police must be familiar with alternative standards anyway. Although protective sweeps might be legitimate in certain circumstances, the courts should not create a flat waiver of the warrant requirement too readily. As commentators have suggested, bright-line rules are not always preferable to individual determinations, as individual determinations may be better at finding the right result. ${ }^{91}$

Fifth, this bright-line rule creates perverse incentives. For example, the police will have strong reasons not to arrest a person on her porch, for by waiting until the suspect enters the house to make the arrest, police can obtain the authority to sweep. The rule increases the chances that police will invade the privacy of the home, unless officers believe that the risks of entry outweigh the potential benefits of the sweep.

\section{B. Traditional Fourth Amendment Analysis: Distinguishing Be- tween Threats}

It is worth reconsidering at this point the constitutional interest at stake: the privacy of the home. The fourth amendment traditionally has afforded private dwellings the greatest protection, since at common law the home was considered a person's castle. ${ }^{92}$ As the Court has noted, "It is familiar history that indiscriminate searches and seizures conducted under the authority of 'general warrants' were the immediate evils that motivated the framing and

Fourth Amendment does not come into play at all as a limitation upon police conduct if the officers stop short of something called a 'technical arrest' or a 'full-blown search.' " Terry, 392 U.S. at 19.

91 See Note, Police Practices and the Threatened Destruction of Tangible Evidence, 84 Harv.L.Rev. 1465, 1472-74 (1971); Albert W. Alschuler, Bright Line Fever and the Fourth Amendment, 45 U.Pitt.L.Rev. 227, 256 (1984).

${ }_{02}$ The common law drew a sharp distinction between a search of private premises and other kinds of searches. See Daniel M. Harris, The Return to Common Sense: A Response to "The Incredible Shrinking Fourth Amendment," 22 Am.Crim.L.Rev. 25, 27 (1984). See also Payton, 445 U.S. at 601 (an "overriding respect for the sanctity of the home. . .has been embedded in our traditions since the origins of the Republic"); United States v. MartinezFuerte, 428 U.S. 543, 561 (1976) (comparing expectation of privacy in automobiles with that in private residences). 
adoption of the Fourth Amendment." Thus one should not lightly toss aside "the basic principle of Fourth Amendment law that searches and seizures inside a man's house without a warrant are per se unreasonable."

Determining whether a particular protective sweep is reasonable represents a sound alternative to the blanket endorsement of all protective sweeps incident to arrest. To produce consistent results, however, the guiding legal standards must be coherent and easy to administer. It is possible to develop such legal standards for the protective sweep.

Using traditional fourth amendment analysis, one can break the category of protective sweeps into two subsets, the search to protect against injury and the search to preserve evidence. In evaluating the reasonableness of a sweep under each set, the courts should balance the severity of the invasion of privacy against the immediate need to search. Because the urgency of the intrusion depends on whether police are concerned about their safety or merely about the destruction of evidence, courts should not treat all sweeps alike. Two policies support this approach: first, society values public safety more than the preservation of evidence, and second, other alternatives are frequently available to protect evidence. ${ }^{94}$

The following general principles provide a backdrop for developing workable standards for legal sweeps. First, the courts should treat sweeps according to the principles of the exigent circumstances exception. Thus, even where officers have reason to believe that evidence is in imminent danger of destruction or reason to suspect that they are endangered, the court should not uphold the sweep if the officers could have avoided it by responsible law enforcement. One of the fundamental principles of the exigent circumstance exception is that the events surrounding the arrest may not be a product of manipulative or careless police work. As Justice Brennan explains, exigent circumstances will excuse the warrant requirement only where "the emergency giving rise to the warrantless entry could not responsibly have been avoided."95

${ }^{93}$ Payton, 445 U.S. at 583; Coolidge v. New Hampshire, 403 U.S. 443, 477-78 (1971).

24 For example, police may stake out premises to make sure that a third party does not leave with the evidence. Such an option is not available when the concern is that the third party is armed and dangerous.

as Vasquez, 454 U.S. at 988 (Brennan dissenting from denial of certiorari). This notion is tied to the principle that "a warrantless search must be 'strictly circumscribed by the exigencies which justify its initiation.' " Mincey v. Arizona, 437 U.S. 385, 393 (1978), citing Terry, 392 U.S. at 26 . Thus, in Segura, 663 F.2d at 415 , the court deemed a search unconsti- 
Where police have probable cause to search and time to obtain either a telephonic or a standard warrant, but nonetheless neglect to apply for one, courts should not let any subsequent "exigency" excuse the lack of a warrant. ${ }^{96}$

Second, the fourth amendment requires use of the least intrusive alternative. Courts thus must determine whether the police could have avoided a sweep by securing or surveilling the premises from the outside. Even when there is an exigency, police must respond in the least intrusive manner. When police know that no one is on the premises, for example, they should secure the property from the outside. ${ }^{97}$ Even if there are people on the premises, if officers can remain safe or protect evidence by monitoring the premises rather than conducting an interior sweep, the police must choose the former alternative until a warrant issues or circumstances change. ${ }^{98}$ Courts must carefully consider available alternative means of protection, otherwise the protective sweep doctrine will be vulnerable to police abuse.

Third, courts may properly weigh extenuating circumstances surrounding the effort to obtain a warrant. For example, if a police officer attempts to obtain a warrant but subsequently concludes that she cannot wait until the warrant actually issues, the warrantless protective sweep may be reasonable. Occasionally, police officers wait to gather more evidence before approaching a magistrate for a warrant, or are forced to wait and watch until a warrant

tutional where law enforcement agents created the urgency of the situation. The officers had knocked at the door of the suspected drug dealer's hotel room, knowing that the knock on the door would cause the defendant to try to destroy evidence. The court would not use an exigency of the officers' own making to uphold the sweep. See also Morgan, 743 F.2d at 1163 (planned arrest allowed for obtaining a warrant in advance).

On the other hand, where nature will destroy evidence, warrantless searches are constitutional. By definition, police do not contrive these emergency situations. See cases cited in note 8 above.

Where police officers need to search immediately, they should seek a telephonic warrant. Courts should excuse warrantless searches on grounds of lack of time only with reference to the amount of time it takes to obtain a telephonic warrant. Moreover, as one court has noted, "[the state] cannot justify a failure to use the telephonic warrant procedure on the ground that it lacks equipment to record the oral statements of law enforcement officers." Wulferdinger, 782 F.2d at 1477.

The trouble with current practice involving telephonic warrants is that courts first scold police officers for not obtaining one, but then uphold the warrantless search anyway. See, for example, id. at 1477; Cuaron, 700 F.2d at 590; Jones, 696 F.2d at 487. The failure to effect the mandate for telephonic warrants is another example of setting high standards and then not enforcing them. See notes 66-67 and accompanying text.

97 See Veillette, 778 F.2d at 902 n.2.

98 See United States v. Munoz-Guerra, 788 F.2d 295, 298-99 (5th Cir. 1986); Congote, 656 F.2d at 974. See also the discussion of Segura in note 97 above. 
arrives. If exigent circumstances arise in the meantime, the urgency necessitating the sweep is not necessarily self-created. ${ }^{98}$

Assuming that the exigencies are not of the police's own making and that there are no less intrusive alternatives, the following sections set forth the appropriate standards for protective sweeps.

1. The Protective Sweep to Protect Officer Safety. Society values few, if any, interests more than protecting the public from injury. As Terry held, where the intrusion on privacy is not great and the potential danger is significant, it is reasonable to allow a search based only upon an officer's articulable suspicion of danger. ${ }^{100}$ This rationale applies convincingly to those protective sweeps designed to prevent injury to the public and police. ${ }^{101}$ Privacy interests are simply less compelling when life is at risk, and so, in this context, the courts should waive both the warrant and probable cause requirements of the fourth amendment. Thus, to initiate a constitutional protective sweep, an officer need only show reason to suspect that there are armed and dangerous third persons on the premises.

๑2 For example, the court in Wallace v. King, 626 F.2d 1157, 1161 (4th Cir. 1980), analyzed the following circumstances in assessing the validity of the warrantless search: "Whether the entry sought to be made [was] in an area where a magistrate [was] or [was] not readily available, and whether another officer [was] available to keep watch on the premises while an officer [sought] a search warrant. . ." Similarly, the court in United States v. Gray, 626 F.2d 102, 104-05 (9th Cir. 1980), upheld a warrantless sweep where a district attorney declined to apply for the warrant without further evidence of probable cause, and police had persisted in vain to get him to change his mind. On the evening that urgent circumstances arose, both the district attorney and magistrate were unavailable. See also United States v. Allison, 639 F.2d 792, 793 (D.C. Cir. 1980) (police officers first telephoned the U.S. Attorney, who counseled an immediate warrantless search).

${ }_{100}$ One could argue, however, that by applying a lower standard of certainty to certain protective sweeps, courts ironically expose police to unnecessary risk. In certain circumstances, it would be safer for police to leave the scene of the arrest, rather than search the premises for people who might pose a danger to them. See Gary Kelder and Alan J. Statman, The Protective Sweep Doctrine, 30 Syracuse L.Rev. 973, 1022 (1979).

This argument is not compelling. Police should be free to decide whether it is safer to sweep the premises or to retire from the area. As long as the police have reason to suspect that their safety is imperilled, they should be able to act in the most minimally intrusive manner to protect themselves. Often this will entail a sweep of the premises. As Justice Harlan pointed out in his concurrence to Terry: "There is no reason why an officer, rightfully but forcibly confronting a person suspected of a serious crime, should have to ask one question and take the risk that the answer might be a bullet." Terry, 392 U.S. at 33. Similarly, an arresting officer should not have to risk the bullets of the arrestee's cohorts in crime: a protective sweep, based on reasonable suspicions of danger, could address this risk.

101 Situations calling for sweeps are similar to the one that arose in Terry:

both deal. . . with an entire rubric of police conduct-necessarily swift action predicated upon the on-the-spot observations of the officer on the beat-which historically has not been, and as a practical matter could not be, subjected to the warrant procedure.

Terry at 20. 
Nonetheless, law enforcement officers cannot manipulate society's concern for their safety to their advantage. To prevent police from infringing upon privacy interests, courts should ask arresting officers to demonstrate exactly what Terry requires for a stop and a frisk: a minimal, objective basis for their fear of harm. ${ }^{102}$ The grounds for their anxiety must be more than a bare feeling; the suspicion must be founded upon specific, articulable facts. ${ }^{103}$ In determining the reasonableness of the suspicion, the court must consider the totality of the circumstances from the police officer's perspective, taking into account his experience and training. These requirements serve to prevent police from using suspicion of danger as a pretext for a warrantless sweep.

This is a workable doctrine. The Terry reasonable suspicion model went into effect in the summer of 1968. For twenty years, police have operated with the notion that they have a right to stop and frisk a person on the street who appears to be armed and dangerous, so long as the stop and the frisk are based upon articulable observation and not mere hunches. Police can apply the expertise they have acquired in the Terry context to protective sweeps.

In applying the Terry reasonable suspicion test to protective sweeps, a number of factors would be critical in determining the legitimacy of the officer's alleged suspicion. The officer should first possess a reason to suspect there are third persons on the property. ${ }^{104}$ Although a relevant consideration, the suspicion of, belief in, or actual knowledge of the presence of weapons on the premises is not sufficient in itself to justify a protective sweep..$^{105}$ Similarly, the heinousness of the underlying crime alone cannot support a

102 See Kelder and Statman, 30 Syracuse L.Rev. at 1015 (cited in note 100): “[t]he fourth amendment requires that a real need, not a hypothetical concern, be demonstrated, based on specific information, before a search can be deemed reasonable." One court has commented on the search for the appropriate standard as follows:

An overly restrictive view of the [protective sweep] doctrine might expose arresting officers to unnecessary dangers without providing any greater protection to legitimate Fourth Amendment interests. An overly deferential attitude toward officers' suspicions, on the other hand, could seriously infringe upon the right to be free from unreasonable searches.

Wiga, 662 F.2d at 1331 . The Wiga court believed that the reasonable suspicion standard, grounded upon specific articulable information, struck the appropriate balance of interests.

${ }^{103}$ "An unjustified but sincere fear by an officer cannot excuse noncompliance or the protection of the occupants' privacy interest would depend on no more than an officer's anxiety." McConney, 728 F.2d at 1206.

104 See Hatcher; 680 F.2d at 444.

10s See Munoz-Guerra, 788 F.2d at 298: "[W]ithout reason to believe that a criminal suspect was aware of police surveillance, the mere presence of firearms or destructible, incriminating evidence does not create exigent circumstances." 
protective sweep, but it is a valid factor in the overall analysis. ${ }^{106}$ Likewise, if the arrestee has a reputation for operating with conspirators, that is a legitimate element in determining the reasonableness of the search. The time and location of the search are relevant too, since safe withdrawal with the arrestee may be more difficult because of the hour of the arrest or the remoteness of the locale. ${ }^{107}$ On the other hand, if a police officer has reason to suspect that there are armed parties on the premises, this alone is a sufficient basis to support a protective sweep. ${ }^{108}$

The reasonable suspicion test for sweeps, unlike the blanket exception, avoids arbitrary distinctions. Rather than focusing on places, such as inside a dwelling versus outside, the individual determination looks directly to the risk itself. Thus, if an arrest is sufficiently removed from the premises so that there is no reasonable objective basis for suspecting danger from anyone inside, any subsequent sweep would violate the fourth amendment. On the other hand, where officers can demonstrate particular grounds for suspecting that persons hidden on the premises jeopardize their safety-even if an arrest has occurred outside-the protective sweep is reasonable and constitutional. ${ }^{109}$ It may be that the Court

${ }_{108}$ Trafficking in narcotics should not be deemed sufficiently dangerous to excuse failure to obtain a search warrant. See United States v. Spetz, 721 F.2d 1457, 1466-67 (9th Cir. 1983); Hatcher, 680 F.2d at 444 (drug dealing not sufficiently dangerous to allow sweep without greater cause). But see United States v. Marszalkowski, 669 F.2d 655, 665 (11th Cir. 1982) (upholding a warrantless search in part because "drug dealers are likely to be armed and dangerous").

See also Baldacchino, 762 F.2d at 176 (gravity of the underlying offense is a factor in assessing exigency of the situation).

107 See United States v. Whitten, 706 F.2d 1000, 1014 (9th Cir. 1983).

${ }^{108}$ See Munoz-Guerra, 788 F.2d at 297-98 ("were we to confine our attention to the D.E.A. agents' predicament when Munoz-Guerra (a suspected armed drug-dealer) left them standing at the patio door, purportedly to retrieve a key from an adjoining room, we would dispense with the requirement of a warrant")(emphasis added); United States v. Gilbert, 774 F.2d 962, 964 (9th Cir. 1985) (sweep proper where officers "had information that appellant might be in the company of another fugitive who was reported to be armed"); Elkins, 732 F.2d at 1285 (officers knew Elkins was armed and therefore dangerous); Whitten, 706 F.2d at 1014 (upholding sweep on grounds that there were several cars present in the driveway, and a few confederates were known to be armed and in the general area); Jones, 635 F.2d at 1361 (upholding sweep where reasonable to believe that Jones, having fired a gun on main street, was armed and dangerous even though he had retired to his home).

${ }^{109}$ Irizarry, 673 F.2d at 558, is a good illustration of this principle. Immediately after a difficult arrest of three armed suspects in the hallway of a hotel, the police entered the gang's hotel room to ensure that no one else was present. The court found a compelling need to search for another dangerous person.

See also United States v. Burgos, 720 F.2d 1520, 1526 (11th Cir. 1983), finding that "the inevitable delay incident to obtaining a warrant must give way to an urgent need for immediate action." Where an illegal gun dealer whose home was a virtual arsenal jeopardized public safety, 
should require a slightly greater showing of need or certainty of danger before permitting entry of a building when an arrest occurs outside, but under the least restrictive alternative rule, this balancing of interests is a familiar exercise. ${ }^{110}$ Further, where the police have a warrant to arrest, the warrant already authorizes them to enter the home to effect the arrest. ${ }^{111}$ When dealing with officer safety, the courts should consider whether the protective sweep was reasonable based on the totality of circumstances-an inquiry familiar to police officers.

2. The Protective Sweep to Preserve Evidence. The traditional fourth amendment rule-requiring probable cause plus exigent circumstances before a court will waive the warrant requirement ${ }^{112}$ - should apply to evidentiary sweeps. Although there is nothing unusual in this formulation, courts have had difficulty defining what constitutes exigent circumstances justifying the waiver of the warrant requirement for evidentiary sweeps. The task is much easier, however, if one keeps in mind the proper order of values suggested by the fourth amendment: first, privacy; then,

[q]uick action increased the likelihood that no one would be injured. . . . [Thus] [1]aw enforcement officers who have lawfully apprehended a suspect on a portion of a structure. . .which they have reason to believe contains dangerous third persons who might pose a threat to their safety have a right to conduct a reasonable security check of such premises.

The court concluded that under these circumstances, a protective sweep was constitutionally permissible.

For examples of this same principle in the Fifth Circuit, see United States v. Jackson, 700 F.2d 181, 190 (5th Cir. 1983) (entry of a motel room is proper after two persons were arrested outside the room, as it was not known how many individuals were involved in the drug transaction, and it had been reported that the persons were armed); Sheikh, 654 F.2d at 1071. For Ninth Circuit examples, see Whitten, 706 F.2d at 1014; United States v. Astorga-Torres, 682 F.2d 1331, 1334 (9th Cir. 1982); Gardner, 627 F.2d at 910 n.2.

110 Justice Brennan, in his dissent from denial of certiorari in Vasquez, 454 U.S. at 987 and n.3, noted that several cases have allowed a security search where police possessed a reasonable apprehension of violence from within the house as they executed an arrest outside. He nonetheless objected to the sweep in Vasquez because it was "based on nothing more than the officers' 'reasonable belief' that there were additional persons in the apartment who were aware of petitioner's arrest." Id. at 987 . Brennan advocated a greater showing of danger for entry into a home where the arrest is made outside.

${ }^{111}$ Wayne L. LaFave, 2 Searches and Seizures $\S 6.5(\mathrm{~b})$ at 445 (1978), states,

[T] $T$ here seems to be no basis for limiting warrantless searches to save evidence to cases where the police are already within, unless it is believed that the added element of entry without prior approval of a magistrate is uniquely offensive, which hardly seems logical.

The same rationale would apply in the context of protective sweeps to ensure officer safety.

112 Where warrants are issued upon probable cause, the presumption is that the search is reasonable. Similarly, if an officer has probable cause to search, but exigent circumstances prevent her from obtaining a warrant, the resulting warrantless search is nonetheless deemed constitutional. 
safety; then, effective law enforcement.

Regardless of the urgency of the situation, the courts should not authorize any sweep to prevent the destruction of evidence unless the police have probable cause to believe that evidence of a crime is on the premises. If probable cause is established, the court must determine whether there are exigent circumstances. There are three possible formulations: probable cause to believe evidence (1) is threatened with destruction; (2) is in danger of imminent destruction; or (3) is in the process of destruction. Gary Kelder and Alan Statman have rejected the first formulation in favor of the third:

A mere threat of removal or destruction [of evidence] should not qualify as an exigent circumstance that can justify failure to obtain the before-the-fact review of a judicial officer that is "generally required to search a person's home." A more stringent standard is called for,. . . a reasonable basis for the belief that the evidence [is] in the "process of destruction" or removal. ${ }^{113}$

The problem with the third formulation, however, is that it would unreasonably hamper the law enforcement process. If something is undergoing destruction, chances are that officers are already too late. It is perhaps for this reason that no circuit court has adopted this standard.

On the other hand, Kelder and Statman are correct that a court should not allow a warrantless search of a home every time evidence merely is "threatened with destruction." This standard is too nebulous. A police officer might rationally perceive a possibility of the destruction of evidence whenever there is probable cause to believe that evidence is on the premises. A threatened-destructionof-evidence standard thus might reduce in practice to a police officer's having probable cause to believe that evidence is on the premises. This is tantamount to waiving the warrant requirement altogether. ${ }^{114}$ Probable cause to believe that evidence is in danger of imminent destruction strikes a more proper balance, one that is sufficiently stringent without emasculating the powers of the police.

Again, this rule avoids the arbitrary results possible under a blanket sweep exception. The rule does not automatically foreclose

${ }^{113}$ Kelder and Statman, 30 Syracuse L.Rev. at 995 (cited in note 100) (footnotes omitted), quoting Mincey, 437 U.S. at 394.

114 See Note, 84 Harv.L.Rev. at 1473 (cited in note 91). 
recourse to protective sweeps when an arrest occurs outside the premises. ${ }^{110}$ With an exigent circumstances test, the situation taken as a whole determines whether the invasion of the home was justified.The following example illustrates the advantages of individual adjudication over the bright-line rule in the context of protective sweeps to preserve evidence. The police have a warrant to arrest a suspect for trafficking in cocaine, but are unable to obtain a search warrant. The agents apprehend the suspect on her front porch, and she calls out to someone in the building. Immediately the police hear the sound of running water and a toilet flushing. In this case, even though the arrest took place outside, a preventive sweep of the premises is appropriate: the police have probable cause to believe that evidence is in the process of destruction. The risk is just as great whether they are standing inside or outside the premises.

Several criteria will help the courts assess whether the police have probable cause to believe evidence is in imminent danger of destruction. ${ }^{116}$ First, the circumstances must be viewed from the perspective of a trained officer. ${ }^{117}$ Second, where the police have probable cause to believe there is a third party on the premises who knows of the impending or actual arrest, they will have sufficient cause to believe that evidence is threatened with almost certain destruction. ${ }^{118}$ In this now-or-never situation, protective

116 Even Justice Brennan concedes that "a warrantless entry is permissible in exigent circumstances." He suggests that the only situation in which the destruction of evidence' could create sufficient exigency allowing the police to enter and sweep a home is where "there is probable cause to search" and a "reasonable belief" based on articulable facts, that destruction of evidence was imminent." Vasquez, 454 U.S. at 988 (Brennan dissenting from denial of certiorari).

${ }_{110}$ Certain facts--the flushing toilet, running water, burning papers-are almost per se signs of the destruction of evidence. See, for example, United States v. Renfro, 620 F.2d 569, 572,575 (6th Cir. 1980) (sweep permitted where arresting officers knocked on the door, then observed the defendant moving "back and forth" in an upstairs room; sounds of a toilet flushing emanated from the second floor window). Of course, officers need not await signs of destruction in progress. See Hackett, 638 F.2d at 1182 (discovery of hidden transmitter in crate of cocaine creates exigent circumstances).

117 Although the courts will assume this perspective, police nevertheless must have reasonable grounds for their beliefs. See Vasquez, 638 F.2d at 532 (relying on lower court's explicit findings that the officers had "reasonable bases for their belief that additional evidence was present in the apartment and that there might be someone there who could destroy it").

In Cuaron, 700 F.2d at 586 n.4, the court was self-conscious about its announced "reason to believe" standard. Although the court would have upheld the sweep if the officers only had reason to believe the evidence might be destroyed, the court emphasized--over the dissent's protests to the contrary-that "by 'reason to believe' we mean just that: reason to believe. Mere guesswork or a whim will not do."

${ }^{118}$ Assuming that the person could destroy the evidence without leaving the premises. 
sweeps are valid. ${ }^{119}$

Thus the legitimacy of the sweep often will turn on whether the police have probable cause to believe that there is a third party on the premises who knows of the government investigation. ${ }^{120}$ Several factors are relevant to this determination, as the following examples illustrate: ${ }^{121}$

Example 1. The police are conducting a large undercover narcotics operation which entails a series of arrests. One of the arrests occurs in public. It is possible that the head of the narcotics ring either will be informed of the arrest, or will suspect that it has occurred. It may be reasonable to infer that evidence soon will be in danger of imminent destruction.

Example 2. Drug dealers frequently employ runners to deliver drugs and to return with the money from the transaction. ${ }^{122}$ Often the supplier will also send out a person to observe whether the transaction goes according to plan. If police have arrested the runner and become aware of the probable existence of counter-surveillance, they will have probable cause to believe that their undercover investigation has been detected. Evidence is in danger of imminent destruction. ${ }^{123}$

119 See Driver, 776 F.2d at 811 (dicta commenting that where there is a substantial likelihood that someone has discovered or is likely to discover the arrest, this may in itself create an exigent circumstance); Segura, 663 F.2d at 414-15 (declining to uphold the sweep, as officers possessed no reason to believe that third persons were inside the premises or that third persons who could destroy evidence were aware of the arrest outside); Vasquez, 638 - F.2d at 531 (officers had reason to believe that third persons inside the premises were aware of the arrest outside; it was "reasonable to infer that evidence could well be destroyed").

120 Courts often rely on the five factors listed in United States v. Rubin, 474 F.2d 262 (3d Cir. 1973) in assessing the propriety of a sweep. See, for example, Thompson, 700 F.2d at 948; Turner, 650 F.2d at 528. The Rubin court looked to:

(1) The degree of urgency involved and amount of time necessary to obtain a warrant;

(2) reasonable belief that the contraband is about to be removed; (3) the possibility of danger to police guarding the site of the contraband while a search warrant is sought; (4) information indicating the possessors of the contraband are aware that the police are on their trail; and (5) the ready destructibility of the contraband. . . .

Rubin, 474 F.2d at 268 (citations omitted). These factors have proven to be unworkable and have contributed to the confusion among the circuits as to what is required before a search is constitutional. The Rubin test fails to distinguish between searches to preserve evidence and searches to protect people, suggesting that each factor is as important as the others.

${ }^{121}$ In all of these examples, the officers must first establish that they have probable cause to believe that there are, or will be, third persons on the premises.

${ }^{122}$ Several courts have considered the arrest of a runner who is in the process of completing a sale to be sufficient grounds for believing that his boss would be notified of his own impending arrest. See, for example, Moore, 790 F.2d at 16; United States v. Acevedo, 627 F.2d 68, 71 (7th Cir. 1980).

${ }^{123}$ See Wulferdinger, 782 F.2d at 1476 (enumerating several factors which gave police probable cause to believe that evidence was in danger of imminent destruction: (1) an apprehended runner was expected to return with the cash from the drug transaction; (2) police 
Example 3. Police arrest a runner in public. The arrestee calls out to a gathering crowd, "Tell my brother!" The police have probable cause to believe the brother will be so informed and will destroy evidence before a search warrant can be obtained.

Example 4. Police carefully plant a beeper in a package of narcotics. They trail the package to its ultimate destination, and observe its receipt. After a short span of time, however, the transmitter falls silent. The police can reasonably infer that their equipment has been discovered. ${ }^{\mathbf{1 2 4}}$ If the police do not act, evidence is almost certain to be destroyed.

The weaknesses of this formulation arise out of the reluctance of judges to enforce the exclusionary rule ex post and the ability of police to fabricate grounds for believing that evidence was in danger of imminent destruction. These risks, however, are not unique to the protective sweep. They are inherent in any use of the exclusionary rule. The protective sweep model proposed here will strike the proper balance between privacy interests and the law enforcement process if judges are sensitive to the vulnerabilities of the exclusionary rule.

\section{CoNCLUSION}

The protective sweep should not be added to the expanding list of exceptions to the warrant requirement. Courts should not regard the goal of efficient law enforcement as paramount by comparison to the threat of arbitrary warrantless searches. While ad hoc determinations of constitutionality are more difficult to administer in theory, a blanket protective sweep exception in practice would not result in significant savings for either the courts or police officers. Moreover, individual consideration of the reasonableness of sweeps will approach the correct result more readily than a flat exception.

Courts should uphold protective sweeps only where officers have reason to suspect their safety is endangered, or probable cause to believe that evidence is in imminent danger of destruction. Police are already familiar with both the reasonable suspicion

were aware of possible counter-surveillance; (3) the public arrest of the runner might have enabled an onlooker to notify the others; and (4) when the police knocked on the door of the suspect's premises, he ran to the back of the house shouting, "The cops are here!"); Hicks, 752 F.2d at 382 (probable cause to believe that there were persons in the defendant's residence who would destroy evidence was established on the basis of defendant's use of counter-surveillance).

124 See Hackett, 638 F.2d at 1182. 
standard announced by Terry, and the probable cause plus exigent circumstances criteria used widely in police work. With time and consistent application, the two-tiered protective sweep doctrine proposed here can produce a body of law to guide police officers confronted with the risk of third persons on the premises. ${ }^{125}$

${ }^{225}$ The negligence standard provides one example of this. Once it was new, but by now the courts and the public have come to understand what "due care" means. It is wrong to suggest that such a process will take place only when one establishes a bright-line rule. See Alschuler, 45 U.Pitt.L.Rev. at 256 (cited in note 91). 